\title{
The Optimization of e-Court Integrated System in Providing Access to Justice During the Covid-19 Pandemic
}

\author{
Aju Putrijanti ${ }^{1}$, Anggita Doramia Lumbanraja ${ }^{2}$, Aditya Yuli Sulistyawan ${ }^{3}$ \\ \{ayuputriyantirubismo@gmail.com ${ }^{1}$, anggitalumbanraja@live.undip.ac.id², \\ adityayulisulistyawa@lecturer.undip.ac.id $\left.{ }^{3}\right\}$
}

Universitas Diponegoro, Indonesia ${ }^{1,2,3}$

\begin{abstract}
The pandemic has brought the limitation of on-site court services. It raised the urgency for optimizing the e-Court system. The amounts of e-Court cases have been rising since the outbreak of the pandemic. Integrated services are one of the issues required to be fixed to make the system more effective. This research provides the reference type of integrated system that is suggested for Indonesia e-Court services. This research is conducted by the literature study in normative perspective frameworks. E-Court has developed the PTSP service as a one-stop service. However, these services are still limited to serving within the scope of hierarchical institutions. Meanwhile, in order for court decisions to have legal consequences effectively, they require affirmation from other involved institutions. This requires a transformation of the system integration model from a vertical integration model to a horizontal integration model. So, it will not leave unfinished things for the Court service user to do. On the contrary, the horizontal integration model will make court services much more effective on one side and reduce public mobility on the other side, especially during the Covid-19 pandemic.
\end{abstract}

Keywords: e-Court, Integrated System, Transformation Court Services, Court Management

\section{Introduction}

This pandemic has changed the whole world civilization, i.e., school, work, social relationship, and governance responsibility become complicated and comprehensive compared to the previous condition. It has brought social changes to society [1]. The way we socialized and got access to everything has to adjust and follow the health protocol, without exception, is access to justice [2]. Regulations have also changed to keep that people could fulfill their rights properly and stay healthy for everyone.

As stated in the United Nations Declaration of Human Rights (hereinafter abbreviated as UDHR), everyone is equal before the law. In this pandemic, this right is disturbed because we have to avoid crowd situations. On the other side, there are still problems regarding courtroom regulation which is needed to be solved. In this case, there should be regulations about court administration and court process during the pandemic.

Access to justice is a fundamental right for everyone, Indonesian Constitution in Article 28. The fulfillment of this right is under Law Number 39 of 1999 concerning Human Rights stated in Article 2. Therefore, states admit and uphold human rights and freedom as fundamental rights 
that can not be separated and protected, respected, and enforced to human dignity, welfare, happiness, and justice.

States should guarantee that everyone is entitled to get their rights, also for rights to justice. Some countries remain ruling the strict regulations to reduce human transmission of Covid-19. In South Africa, they issued guidance to Court including limiting physical distancing in the courtroom except for urgent and essential matters, while India and Nepal give guidance on how courts can operate safely by allowing lawsuit file submission via e-mail, using video conference for hearings, in Portugal, for hearing and judgments in the lower courts are remotely and in the U.S. hearing process remotely so do the judgments [3].

In Indonesia, during the pandemic, reach 824 cases of e-court, not include the criminal process. When the previous research takes, Supreme Court had not been launched the regulation e-court for the criminal justice system [4]. In Latvia, they decided to use a digital platform during the pandemic since it is not possible to shut down the legislative, executive, and judicative activities. Based on the rule of law and democracy principle, it needs special requirements to implement its functions [5]. The judiciary role has an important role in keeping the democracy. The rule of law still continues. It has to redefine its process in adjudicating the cases since it is a fundamental right that can not be ignored.

The modernization of technology should be appropriately used for civilization. At the same time, in pandemic situations, physical distancing is a must, and circumstances have to change some common values in regard to the judiciary system. The technology ensures that the function of governance, either executive or judicative, still operates using digital platforms properly. China started implementing digital systems such as big data, cloud computing, artificial intelligence to improve and transparency efficiency to develop judicial reform and shifted from judicial -system innovation to judicial- technological innovation. These efforts lie in the concept of legality, implantation of behavior from the government and the society [6].

The digitalization era influences people's behavior in how they interact with others in social media and the government's matter. The shifting paradigm from modern life to digital life can not be avoided. Otherwise, we will be left behind everything. These circumstances trigger to make new regulations, in addition to the pandemic, as life keeps on going without knowing when the pandemic will end.

The article is an effort to question and seek the answer to the implementation of Indonesia e-Court and the reference type of integrated system needed to be applied in the Indonesia eCourt system.

This article is a result of legal research with the legal study method, using a literature study to provide the research material, such as the Indonesian regulations regarding e-Court, journal articles, thesis, and several books regarding the judiciary system in Indonesia.

\section{The Implementation of e-Court System in Indonesia}

Access to justice is important. It is one goal of seventeen goals of Sustainable Development Goals (SDGs). It launched in September 2015 and was adopted by UN member states in 2015. However, it needs strong commitment from stakeholders to make it becomes a reality.

Justice has always been an interesting topic since ancient times, so does the meaning have a broad understanding of different opinions from ethical, social justice, substantive justice, and others. Meaning the word of justice had been changed followed human civilization, it is not only 
legal aid to whomsoever or the procedure of the Court, but it also covers other forms of injustice, while it has a wide meaning related to modern states and governance.

Access to justice can not be defined precisely, but it can be understood as a way for people to get justice if they have case law. For some people, the obstacles i.e, the lack of knowledge of making lawsuits, gender, children, poor transportation, and geographic conditions, can be more complex when there is no infrastructure to support societies. The various type of obstacles may differ in each country.

Rights to get access to justice regulated in Article Number 27 of Constitution and the implementation to get justice supervised by Supreme Court and Constitutional Court; under Supreme Court, there are general Court, religious Court, military Court and administrative Court based on each regulation for their competence.

Conventional courts should shift to electronic Courts due to modernization, digitalization, and globalization in every path of human life. In 2010, Supreme Court had issued a Supreme Court Circulair Letter Number 10 of 2010 concerning Electronic Document as a Supporting File to Cassation and judicial review, then renew with Supreme Court Circular Number 1 of 2014. This circular as an embryo to build e-litigation for today.

In the Annual Year Report of Supreme Court 2018 with the title New Era of Modern Judiciary Based on Information Technology more strengthen the aims to implement e-courts. In performing the aims, Supreme Court stipulates Supreme Court Regulation Number 3 of 2018 concerning Electronic Case Administration in the Court. This regulation is replaced by Supreme Court Regulation Number 1 of 2019 concerning Case Administration and Court Electronically is regulation for general Court, religious Court, administrative Court, military Court, except criminal Court. For criminal Court, there is Regulation of Supreme Court Number 4 of 2020 concerning Case Administration, and e-Court in Criminal Court had been legalized in September 2020.

Judiciary system has a complex system which should consider special condition for certain system. The implication of pandemic should not ignore the access to justice, and has to maintain the relevant procedures and to promote, ensure the continuity all system of courts.

There is a challenge for the Supreme Court to find the right way to keep the balance between the rights of the citizen, the interest of the public, state purposes. On the other side, there should be no restrain to receive and examine cases that came to Court to get justice. Citizens might have difficulties facing the changing situation in this pandemic, and the Supreme Court has given a solution to solve it.

In Czech Republic, Supreme Administrative Court considered to postponed the Senate byelection by the government's decision in the state of emergency and added a general note stated that not only health, life, economics to be protected but also the democracy and the rule of law. There should be preparedness, flexibility, openness and open dialogue is necessary to find the right balance between the executive emergency situation, to prevent the spread of disease, and the judicial institution [7]. It shows that it is important harmonization between the legislative, executive, and judicative to protect the citizen's rights, included rights of democracy.

Under the Human Rights Act 2004 in Australia may also provide a standard for litigation all jurisdictions to determine the measures and make their services for the public without ignoring the risk of the pandemic [8].

This pandemic triggers the people to use e-court instead of conventional Court, as suggested by the government. Before the pandemic came, most people did not use e-court. They like to go the Court as it used to be, even the Supreme Court Regulation had been stipulated.

The advantage of e-court, it gives benefit to both parties because it is simple, low-cost, fast, but on the other hand, there are some problems and challenges to solve [9]. Problems and 
challenges are the preparation of regulations, infrastructures, and culture, especially the internet crime that might happen because of the leak of data.

Beyond the problems and challenges, e-court is very helpful to get access to justice in this situation. As stated by Kukuh Santiadi, there are several advantages implementation of e-court, first, as an effort of Supreme Court to minimize the three obstacles of Court, second is to create superior and transparent judicial process and mechanism, three, impact the efficiency of administrative justice, fourth, it is beneficial for justice seekers to save the cost since they have easy access to control all the process electronically [10]. Another benefit of using e-court, it can reduce bribery crime in the Court, the harassment of the Court, modernizing the judiciary system [11] [12].

The uncertainty of when the pandemic will end should make us think deeper since pandemic still takes place, it is advised to people to use e-court in order to fulfill their rights. The existence of e-court is beneficial in this pandemic. People still keep on fulfilling their rights by using ecourt, there is no delay, no boundaries to put lawsuits, and this is a good phenomenon for the justice system.

In order to improve services to the community seeking justice use realizing fast, easy service, it is necessary to be transparent, scalable, and affordably implemented changes to the service system. Change in the service system is a service that is carried out in a manner integrated into a single process that begins from the initial stage to the stage high court service product settlement

and district courts through one door. These services are required "one door one-stop service" (in Bahasa: Pelayanan Terpadu Satu Pintu, abbreviated as PTPS) as appropriate with court functions. PTSP is an integrated service in a single process starting from the initial stage up to the stage of product completion court services through one door. PTSP is conducted by the High Court and District Court.

According to the annual report of the Indonesian Supreme Court in 2020, implementation of PTSP throughout the judicial environment under the Supreme Court has reached the 100 percent mark. The integrated e-Court table in the PTSP system facilitates every problem faced by judicial service users, especially other users, to get an account if the public wants to litigate and hear electronically in Court. Therefore, the optimization of PTSP supports the complete transformation of the court work process into the Electronic System currently being implemented. In addition, this policy is in accordance with the initial goal of PTSP to realize a simple, fast, and low-cost judicial process, provide easy, definite, measurable, and corruptionfree administrative services to Service Users and maintain independence and impartiality of court officials. Thus, PTSP will improve court performance and services as well as community satisfaction.

Supreme Court policy in encouraging the use of information technology in Court encourages the judicial bodies under the Supreme Court to develop innovations to improve organizational performance and public services. As a result, some innovations such as PTSP Virtual Assistant application, Online PTSP application, CCTV Online application, Online License Virtualization application, Data Bank, Divorce Deed Validation Application have been implemented since 2019. 


\section{Paradigm Transformation from Old Public Services into New Public Service}

E-Court refers to the use of technology by the judiciary to provide web-based remote services by using Internet applications to improve access and delivery of information and services to court service users and government entities. E-court can build better relations between the courts and the public, making inter-court interactions and communications with citizens smoother, easier, and more efficient. The use of electronic-based services is indeed more effective in delivering information, and services are becoming faster, cheaper, and easier to be accessed by public, especially during the Covid-19 pandemic.

PTSP, which has been developed by the Indonesian Supreme Court in accordance to facilitate the e-Court system, has shown the development of the Court services process. According to Layne \& Lee four stages of integrated public services described in Figure 1, PTSP has stepped the integrating process in the level of Vertical Integration. Basically, PTSP is one door service but only providing the services in the hierarchical institution frameworks. The technology and organization in PTSP are considered being complex enough to bring it to the integrated model system.

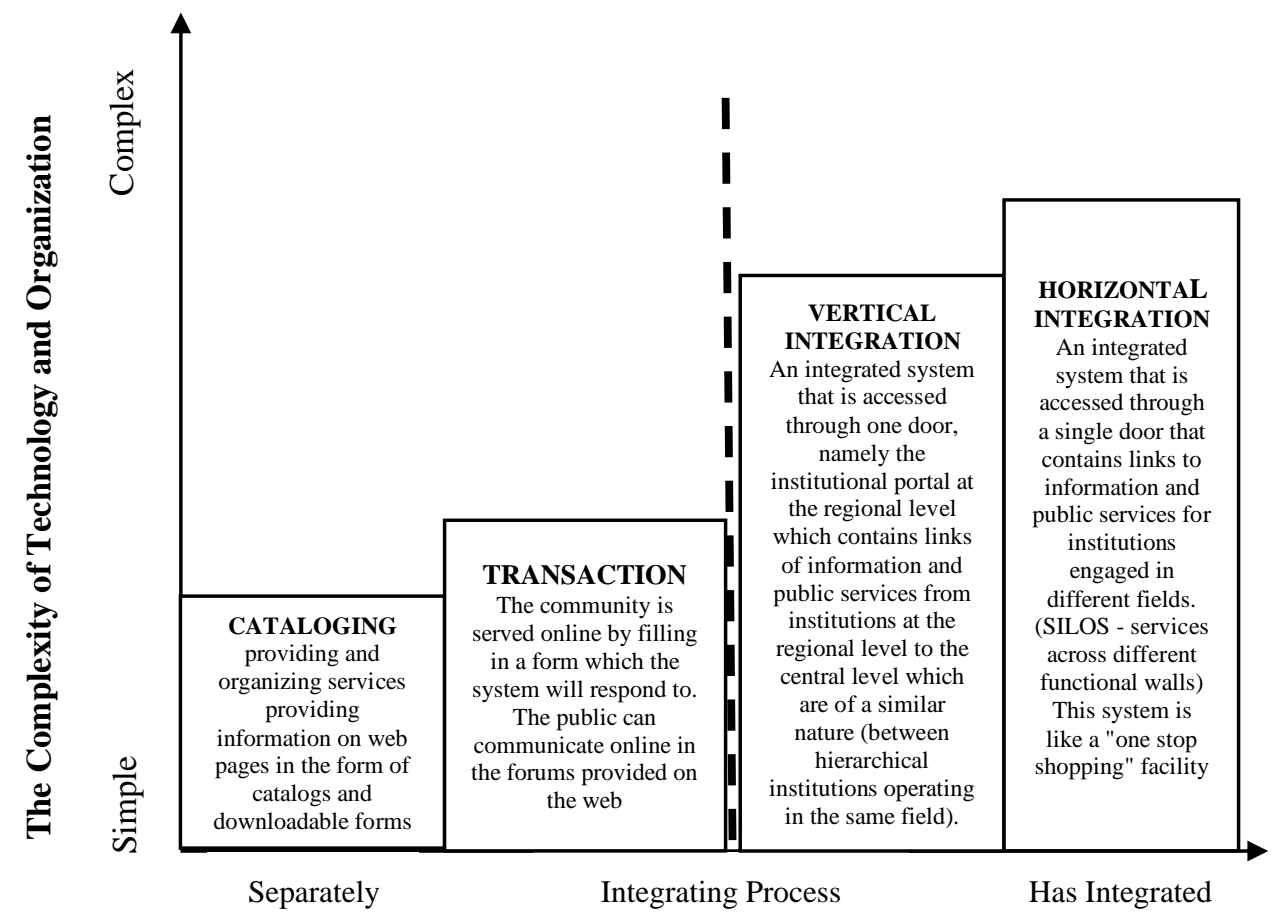

Fig. 1. Dimensions and Levels on electronic-based of Public Services Development [13] [14].

To enhance the Court services, Supreme Court needs to consider about optimization integrated model system into the Horizontal Integration level. Not only as an integrated system through one door but also providing a holistic service, we call it as "one stop shopping" that is 
engaged with another institution (outside of the judicial body). Take, for example, after validating the divorce deed, The Court service user needs to update the information of the marital status in the District Civil Registry Office, as well as the deed of adoption. The vertical integrating model still leaves much-unfinished homework for court service users to do. PTSP may have started to make it easier for Court service users to access court services without having to go to the Court. However, the one-stop service will not be effective if it is not supported by inter-institutional services that are interrelated in the horizontal integrating model.

In developing a system integration model from vertical integration to horizontal integration, Supreme Court needs to cooperate and provide services between institutions and several related institutions, such as Public Prosecutor institution, Civil Registry Office, Advocate Law Office, Ministry of Law and Human Rights, Notary Office, and the other stakeholders.

Covid-19 has taken a role as a digital accelerator transformation in public service delivery. All public services depend on digital services as the only option. The biggest challenge that must be faced is not limited to the Covid-19 pandemic issue only but also to the digital transformation in civilization future. This problem is very close to the technology things, social challenges phenomenon, and the parties which are connected to digital transformation. Information can be collected, and personalized services can be implemented through catalog models and transactional models. However, looking for the best technology that specifically supports judicial management may be possible causing delays and stagnation. The new transformational ministry will be the key to dealing with this new arrangement, requiring a new paradigm, adequate assets, professional human resources, and other required resources [15].

The biggest challenge in bringing PTSP into a horizontal integration model is defeating sectoral egos and increasing the extreme cooperation between institutions by adopting a paradigm shift from the old public service paradigm to the new public service paradigm. In Table 1 we see how the paradigm shift of public service from old public service to new public service paradigm. From here, we realize that the demands for change are not solely on technology, organizational systems, and judicial management but also on public servants mindsets.

Table 1. Differences of Old Public Services and New Public Service [16] Old Public Services New Public Services

The Public servants are responsive to the The Public servants are responsive to the clients and constituents (involved parties) citizens

The role of the institution is "Rowling". The The role of the institution is "Serving". institution designing and implementing The institution negotiating and bridging policies only for certain parties (the the interests of citizens, and community domination of political interest) group, creating shared values

The accountability is approached by the Using the multifaceted model to approach hierarchical model (subordinate system) accountability. Public servants could accommodate the interest between the law, community values, political norms, and citizens

\begin{tabular}{ll}
\hline Only allowed limited discretion & $\begin{array}{l}\text { Discretion is most needed with the } \\
\text { constrained and accountable } \\
\text { responsibility }\end{array}$ \\
\hline The motivation of public servants is assumed & $\begin{array}{l}\text { The motivation of public servants based } \\
\text { on the passion for contributing to the } \\
\text { based on pay and benefits }\end{array}$ \\
\hline
\end{tabular}


The mindset of "Serving" in the new public service paradigm is urgently needed to optimize one-stop E-Court services in Indonesia. The Court in this case plays a role in negotiating and bridging the interests of citizens and community groups, creating shared values within the framework of democracy, namely prioritizing the values of the public interest above all else.

Accountability indicators Court institutions are not only affirmed by the hierarchical institution but also need to be affirmed by the public. It is a consequence of partnership model which is stated by Fang [17]. Courts must also have the courage to take discretion based on the principles of appropriateness, applicable laws and regulations as well as general principles of good governance. The normative approach that is very thick in the old public service paradigm can hinder the Court in developing its services, especially to address problems arising from inter-agency service practices (the issue of sectoral ego needs to be given attention). This paradigm transformation is very relevant with the Paradigm Concept of Guba \& Lincoln. In the Guba and Lincoln's positivism paradigm is very near to the Old Public Service Paradigm concept. The public servants are limited to do discretion, as they are required to do their service normatively in the "Rowling" model. The political interest conducts the service. Meanwhile, the New Public Service Paradigm concept is very near to Guba and Lincoln's constructivism paradigm. The New Public Service Paradigm is trying to change the "Rowling" model into the "Service" model that requires the public servant to take a role in negotiating and bridging the interests of citizens, and community groups, creating shared values. Of course, it is in harmony with the description of Epistemology (Transactional and Subjectivitist) and Methodology (Hermeunitical and Dialectical) of Guba and Lincoln's Constructivism Paradigm [18].

Courts must uphold the spirit of contributing to community development. The Court is not an inanimate object but should be transformed into an institution that lives and develops together with society to meet the needs of society according to the demands of democracy.

In a democracy-based society such as Indonesia, values such as efficiency and productivity must not be lost but must be placed in context the greater one in the public interest. The new public service paradigm is the basic foundation of democracy to provide the best service to society in the midst of all the challenges of the times that must be faced one and another. Public servants must be brave take a risk in shooting for the sky to develop their services, including the judiciary body. The vision of achieving a full system integration model and accommodating the public interest as the highest priority scale must be taken by court institutions to respond to the challenges of the times.

\section{Conclusion}

The Covid-19 pandemic demands large-scale restrictions on the mobility of people. this creates obstacles for the community to access justice. E-Court, which has been initiated since 2019 by the Indonesia Supreme Court, is the only alternative to provide long-distance services, so that court service users do not have to come directly to the court. This internet-based service has been developed in a modern and quite complex manner. However, there is still some homework to optimize the one-stop service delivery. This requires Indonesia Supreme Court to develop PTSP from a vertical integration model to a horizontal integration model. The biggest challenge in improving the integrated service is the demand for a paradigm shift from the old public service paradigm to a new public service paradigm. This demand must be fulfilled by the judiciary to answer demands for democracy that prioritizes the public interest above all else. 
The use of internet in judiciary system is become important as a part to develop New Public Service in order to provide access to justice for everyone.

\section{Acknowledgments}

We gratefully acknowledge that the research was financially supported by Faculty of Law, Universitas Diponegoro, Indonesia.

\section{References}

[1] J. Benach, "We Must Take Advantage of This Pandemic to Make a Radical Social Change: The Coronavirus as a Global Health, Inequality, and Eco-Social Problem.” International Journal of Health Services, vol. 51, no. 1, Jan. 2021, pp. 50-54, doi:10.1177/0020731420946594.

[2] G. Pleyers, "The Pandemic is a battlefield. Social movements in the COVID-19 lockdown", Journal of Civil Society, 2020, 16:4, 295-312, doi: 10.1080/17448689.2020.1794398

[3] C. for R. Rights, "Access to Justice During the COVID-19 Pandemic," 2020.

[4] A. D. Lumbanraja, "Perkembangan Regulasi Dan Pelaksanaan Persidangan online di indonesia dan amerika serikat selama pandemi covid-19," J. Crepido, vol. 02, pp. 46-58, 2020.

[5] I. Ziemele, "Liberal Values, Covid-19 and the Judiciary," Eur. Conv. Hum. Rights Law Rev., vol. 1, no. 2, pp. 159-164, 2020, doi: 10.1163/26663236-bja10010.

[6] B. Hoffmaster, "Judging Rationally," Can. J. Law Jurisprud., no. 1, pp. 85-104, 2021, doi: 10.1017/cjlj.2020.20.

[7] J. Petrov, "The COVID-19 emergency in the age of executive aggrandizement: what role for legislative and judicial checks?," Theory Pract. Legis., vol. 8, no. 1-2, pp. 71-92, 2020, doi: $10.1080 / 20508840.2020 .1788232$.

[8] K. Evans and N. Petrie, "COVID-19 and the Australian Human Rights Acts," Altern. Law J., vol. 45, no. 3, pp. 175-179, 2020, doi: 10.1177/1037969X20942861.

[9] M. B. Kurniawan, "Implementation of Electronic Trial (E-Litigation) on the Civil Cases in Indonesia Court As a Legal Renewal of Civil Procedural Law," J. Huk. dan Peradil., vol. 9, no. 1, p. 43, 2020, doi: 10.25216/jhp.9.1.2020.43-70.

[10] K. Santiadi, "Expanding Access To Justice Through E-Court In Indonesia," Prophet. Law, vol. 1, no. December, pp. 75-89, 2019, doi: 10.20885/PLR.vol1.iss1.art5.

[11] D. Putra, "a Modern Judicial System in Indonesia: Legal Breakthrough of E-Court and E-Legal Proceeding," J. Huk. dan Peradil., vol. 9, no. 2, p. 275, 2020, doi: 10.25216/jhp.9.2.2020.275297.

[12] A. Putrijanti and K. C. S. Wibawa, "The Implementation of E-Court in Administrative Court to Develop Access to Justice in Indonesia". Journal of Environmental Treatment Techniques, vol.9, no.1. pp. 105-109. https://doi.org/10.47277/JETT/9(1)109

[13] K. Layne and J. Lee, " Developing Fully Functional E-Government : A Four Stage Model". Government Information Quarterly, Vol 18, Issue 2, pp 122-136. https://doi.org/10.1016/S0740624X(01)00066-1

[14] A. D. Lumbanraja, "Urgensi Transformasi Pelayanan Publik melalui E-Government Pada New Normal dan Reformasi Regulasi Birokrasi," Administrative Law and Governance Journal, vol. 3, no. 2, pp. 220-231, Jun. 2020. https://doi.org/10.14710/alj.v3i2.220-231

[15] D. Agostino, M. Arnaboldi and M. D. Lema, "New development: COVID-19 as an accelerator of digital transformation in public service delivery". Public Money \& Management, 2020 DOI: $10.1080 / 09540962.2020 .1764206$

[16] J. V. Denhardt and R. B. Denhardt, "The New Public Service", 2003, Armonk, New York : M.E. Sharpe 
[17] Z. Fang, "E-Government in Digital Era: Concept, Practice, and Development". International Journal of The Computer, The Internet and Management, 2002, vol. 10, no. 2, pp 1-22.

[18] E.G. Guba and Y. S. Lincoln, "Competing Paradigms in Qualitative Research" in N.K. Denzin \& Y.S. Lincoln (Eds), "Handbook of Qualitative Research", 1994, pp. 105-117. London: Sage. 